\title{
Investigation of Meaning of Leisure Activities and the Satisfaction with Life of Students in the Faculty of Sport Sciences: An Example of Akdeniz University
}

\author{
Alkan Uğurlu ${ }^{1}$, K. Alparslan Erman ${ }^{2}$, Emine Bal Turan ${ }^{3}$, Tolga Öksüz², Abdullah Güngör ${ }^{4}$ \\ ${ }^{1}$ Department of Physical Education and Sport Education, Faculty of Sport Science, Akdeniz University, Antalya, Turkey \\ ${ }^{2}$ Department of Sport Management, Faculty of Sport Science, Akdeniz University Antalya, Turkey \\ ${ }^{3}$ Department of Recreation, Faculty of Sport Science, Akdeniz University Antalya, Turkey \\ ${ }^{4}$ Institute of Social Science, Akdeniz University Antalya, Turkey \\ Correspondence: Alkan UĞURLU, Faculty of Sport Science, Akdeniz University, Antalya, Turkey.
}

Received: November 26, 2017

Accepted: December 24, 2017 Online Published: December 28, 2017

doi:10.11114/jets.v5i13.2897

URL: https://doi.org/10.11114/jets.v5i13.2897

\begin{abstract}
Aim: It is known that recreational activities have positive effects on people's emotions, thoughts, morale and many other issues. The aim of this study was to measure students' participation in recreational activities, life satisfaction and the meaning of leisure activities to the students in the Faculty of Sport Sciences at Akdeniz University.

Method: A total of 252 students (60.3\% male, 39.7\% female) participated in the study. As data collection instruments, Turkish version (Köker, 1991) of Life Satisfaction Scale (LSS), which was developed by Diener et al. (1985), and Turkish version (Gürbüz et al., 2007) of Leisure Meanings Inventory (LMI) (Esteve et al., 1999) were used. SPSS Package program was used in the study. ANOVA was used in the data analysis.

Findings: According to the findings of Leisure Meanings Inventory by classes, there was a statistically significant difference ( $\mathrm{p}<0.005)$ among the groups. . This difference appears to be between sophomores and juniors when examined on a class-by-class basis. According to the findings of Leisure Meanings Inventory with regard to departments, it was noted that there was very little difference between them, although there was a difference in the averages. This difference was not statistically significant though. There was no statistically significant difference between groups regarding class and department variables according to the findings of Life Satisfaction Scale.

Conclusion: The results of this study showed that there was a significant difference between sophomores and juniors while there was no significant difference between freshmen and seniors according to the LMI averages. There was no significant difference between the mean scores of LSS among the classes.
\end{abstract}

Keywords: recreation, life satisfaction, leisure meanings

\section{Introduction}

The concept of time we use a lot nowadays is actually created and used with the aim of carrying out the flow of life in a system created by mankind. People are using time to adjust their working hours, resting hours, holidays, meal times, sleeping time and their lives in a certain order. In the development of human being, shaping the flow of life, in the regulation of daily activities, and in any field, the share of understanding of time in professional success is great. Societies that organize business life, social relations, entertainment and resting habits within this understanding are more developed than others (Karaküçük, 1999). At this point, how time will be assessed is of great importance. If time is wasted, progress and progress can not be achieved. Using time well depends on the ability to establish a good balance between the time units that a person devotes to himself / herself, working life, social life, rest and enjoyment, and meeting their biological and physiological needs (Karaküçük, 1999).

Biological and Physiological needs and free time outside of the time allocated for working life can be used for the time that is completely free for itself. Leisure is a part of free time and spent with specific occupations (Mieczkowski, 1990). Recreation, on the other hand, is defined as leisure activities in general terms. Tillman (1974) categorized the basic needs for recreation as follows; new experiences like adventure, relaxtion, escape and fantasy, recognition and identity, 
security- being free from thirst, hunger or pain, dominance-to direct others or control one's environment, response and social interactions, to relate and react to others, mental activity- to perceive and understand, creativity, service to others-the need to be needed, physical activity and fitness.

Torkildsen (2005) grouped the factors affecting participation in leisure activities under three headings:

individual factors: the stage of an individual's life, his or her interests, attitudes, abilities, upbringing and personality

the circumstances and situations in which individuals find themselves: the social setting of which they are a part, the time at their disposal, their job and their income

opportunities and support services available to the individual: resources, facilities, programmes and activities; their quality and attractiveness; and their management.

Participation in recreational activities also helps people to get satisfaction in life. Life satisfaction is the emotional reaction of the individual outside his work life. In other words, it is the general attitude towards the fact of life (Özdevecioğlu, 2003). According to another approach, life satisfaction represents judgments about subjective well-being and quality of life, based on events in the individual's life (Dikmen, 1995). ---There is uncertainty in the definition and scope of the concept, depending on the level of perception of life satisfaction different from person to person. That is why; there are many different approaches in the literature. According to Schmitter (2003), satisfaction has been affected by the factors like taking pleasure in life, finding life meaningful, consistency at the matter of reaching goals, positive individual identity, feeling well physically, economical security and social relationships( Cited: Capri, Özkendir, Özkurt \& Karakuş, 2012)

Sociodemographic factors such as age, health, gender, working status, work, education, religion, marital status, as well as levels of participation in physical activity and leisure activities affects Life satisfaction (Karataş, 1988, Karataş ve diğ., 1989: Cited: Şener 2009). The high level of life satisfaction plays a very important role in our lives because it affects individuals' personal development positively (Rodriguez et al., 2007).

The aim of this study is to determine whether there are differences in the part of the students and the class based on the evaluation of leisure time of sport science students and the meaning of leisure time and evaluation of life satisfaction during this evaluation.

\section{Method}

\subsection{Participants}

Population of the research consists of the students of the Faculty of Sports Sciences of Akdeniz University. A total of 300 students agreed to take part in the study but 252 students returned.

\subsection{Data Collection}

A questionnaire consisting of 3 parts was used as data collection instrument. The first part is directed towards the demographic information prepared by the researchers and includes questions about the participant's participation in the free time activities, such as participation frequency, form, reasons for participation.

In the second part, there is a life satisfaction scale. Diener et al. (1985) adapted the Turkish version of the Life Satisfaction Scale by Köker (1991). The scale is a self-assessment scale consisting of 5 items of Likert type, ranging from 1 (not expressing me) to 7 (expressing me completely).

The third part is Esteve et al., Which consists of a total of 35 items measuring how the individuals participating in the study felt when they participated in leisure activities. (1999) and translated into Turkish by Gürbüz et al. (2007). Participants were asked to rate the expressions on the scale using Likert type 6 ("I do not agree" = 1 and "I totally agree" = 6) interspersed options.

\subsection{Data Analysis}

In the study, \% frequency and ANOVA test were applied for data analysis.

\section{Results}

The average age of the students participating in the survey is 21.96 (22 years 35.7\%, 21 years $21.4 \%$ ). The youngest age is 19 and the largest age is $29.60 .3 \%$ were male, $39.7 \%$ were female. $27.4 \%$ of them read Physical Education and Sports Education, 29.4\% Sports Management, 18.7\% Department of Coaching Education and 24.6\% in Recreation Department. Classification distributions consist of $36.9 \%$ in the 4 th class, $27.4 \%$ in the 3 rd class, $29.8 \%$ in the 2 nd class and $6 \%$ in the 1 st class students.

$75.4 \%$ of the students who participated in the survey stated that their economic situation is in the middle (we can meet our needs) and $14.7 \%$ is in the Bad (we can not fully meet our needs) level. The number of students who are very good 
(we spend money like we want) is $8 \%$.

When the income levels of the students are examined, the lowest student is $1000 \mathrm{TL}$ and below, 1 student is the highest, and the highest student is 4001-5000 TL. The majority of the students participating in the study (72.6\%) have income levels between $2000 \mathrm{TL}$ and $3000 \mathrm{TL}$.

It is seen that the students participating in the study prefer to participate in recreational activities for 11-15 hours per week predominantly $(43,3 \%)$ when the participation periods for weekly recreational activities are examined. In the study, the number of students with 1-5 hours of participation in the study constituted 25 and $9,9 \%$ of the total number of the participants, while the duration of participation is 16 hours and the participation rate is 40 , covering $15,9 \%$ of the total.

When the frequency of participation in weekly recreational activities is examined, it is seen that students prefer to participate in recreational activities 3 to 4 times a week predominantly $(49.6 \%)$. It is observed that students participate in these activities with $93.7 \%$ of their friends, $35.3 \%$ alone and $19.8 \%$ with their families and also according to the types of activities; 98.4\% were active in sports activities, $92.9 \%$ in Social Activities and $89.7 \%$ in Active and Cultural Activities. When the reasons why students participate in these activities are examined; $90.9 \%$ were "fun", $88.9 \%$ were "wanting to be with friends", 50.4\% were "to relax" and 61.9\% were "in order to get rid of stress and stress".

Table 1. Means of life satisfaction scale of participants by departments

\begin{tabular}{llllll}
\hline Department & M & N & S. D. & f & Sig \\
\hline Physical Education and Sport Education & 22,5507 & 69 & 3,41509 & & \\
Sport Management & 22,2432 & 74 & 2,23184 &, 368 &, 777 \\
Coaching Education & 22,4468 & 47 & 2,30131 & & \\
Recreation & 22,6935 & 62 & 2,05330 & & \\
Total & 22,4762 & 252 & 2,57544 & &
\end{tabular}

In Table 1, no statistically significant difference was observed in the life satisfaction according to the participants' sections.

Table 2. Mean of Participants Meaning of Leisure Time Meaning by Departments

\begin{tabular}{llllll}
\hline Department & M & N & S. D. & f & Sig \\
\hline Physical Education and Sport Education & 162,3333 & 69 & 12,00939 & & \\
Sport Management & 163,6892 & 74 & 10,00538 & & \\
Coaching Education & 162,6809 & 47 & 8,79008 & \multirow{2}{*}{293} &, 830 \\
Recreation & 163,8065 & 62 & 12,01616 & & \\
Total & 163,1587 & 252 & 10,85611 & & \\
\hline
\end{tabular}

In Table 2 , it is observed that although there is a difference between the sections in terms of idle time, there is very little difference between the sections. This difference is not statistically significant.

Table 3. Mean of Participants' Leisure Time Meaning by Classes

\begin{tabular}{llllll}
\hline Class & M & N & S.D. & f & Sig \\
\hline 1 & 160,2000 & 15 & 2,59670 & & \\
2 & 166,7467 & 75 & 9,53811 & & \\
3 & 160,6667 & 69 & 10,23211 & 4,587 &, $004^{*}$ \\
4 & 162,5914 & 93 & 12,37128 & & \\
Total & 163,1587 & 252 & 10,85611 & & \\
\hline
\end{tabular}

$*(\mathrm{p}<0,005)$

Table 3, shows that there is a meaningful difference between the groups when the meanings of meaning of leisure time between the classes are examined. This difference appears to be between the 2 nd and 3 rd class. 
Table 4. Inter-Class Leisure Meaning Scale Mean Significance levels

\begin{tabular}{|c|c|c|c|c|c|c|}
\hline \multirow{2}{*}{$\begin{array}{l}\text { (I) } \\
\text { Class }\end{array}$} & \multirow[b]{2}{*}{ (J) Class } & \multirow{2}{*}{$\begin{array}{l}\text { Average Difference } \\
\text { (I-J) }\end{array}$} & \multirow{2}{*}{ S.D. } & \multirow{2}{*}{ Sig. } & \multicolumn{2}{|c|}{ 95\% Confidence interval } \\
\hline & & & & & Lower limit & Upper limit \\
\hline \multirow{3}{*}{2} & 1 & 6,54667 & 3,00679 &, 182 & $-1,4502$ & 14,5435 \\
\hline & 3 & $6,08000 *$ & 1,77331 &, $004 *$ & 1,3637 & 10,7963 \\
\hline & 4 & 4,15527 & 1,64983 & 0,74 &,- 2326 & 8,5431 \\
\hline \multirow{3}{*}{3} & 1 & ,46667 & 302850 & 1,000 & $\begin{array}{l}-7,5879 \\
\end{array}$ & 8,5212 \\
\hline & 2 & $-6,08000^{*}$ & 1,77331 & ,004* & $-10,7963$ & $-1,3637$ \\
\hline & 4 & $-1,92473$ & 1,68908 & 1,000 & $-6,4170$ & 2,5675 \\
\hline
\end{tabular}

$*(\mathrm{p}<0,005)$

In Table 4, when the meaningfulness levels of the meaning of leisure time scale between the classes are examined, only a statistically significant difference is seen between the second and third classes.

Table 5. Participants' Life Satisfaction Scale by Classes

\begin{tabular}{llllll}
\hline Class & M & N & S. D. & f & Sig. \\
\hline 1 & 21,6000 & 15 & 2,87352 & & \\
2 & 22,5067 & 75 & 2,75275 & & \\
3 & 22,7246 & 69 & 2,06429 &, 816 &, 486 \\
4 & 22,4086 & 93 & 2,72363 & & \\
Total & 22,4762 & 252 & 2,57544 & &
\end{tabular}

When the life satisfaction scale according to the classes was examined in Table 5, no significant difference was observed.

\section{Discussion}

Participants in the study prefer to participate approximately 11-15 hours a week and 3-4 times a week. Süzer (2000) also stated that students have free time in similar periods. Participation in cultural activities is passive Participation in sports and artistic activities is mainly in the form of active participation.

Participants prefer to participate in recreational activities with their friends, while the reasons for participation are "to have fun", "to be with friends", and "to get rid of boredom and stress" respectively. Süzer (2000) and Demirel (2014) stated that they prefer to spend $60 \%$ of their leisure time with their friends in support of our research.

It is seen that our country youth passively spend their free time during the studies (Abadan 1961, Süzen 2000). However, this result contradicts our study, and students participating in the study show that they are actively involved in leisure activities. In addition, Gökçe (2008) stated that individuals who exercise in their free time, which parallel to our study, provide more Leisure Time Satisfaction.

The averages of the scores of life satisfaction and leisure time scale and subscales of the individuals participating in the study were examined. According to this, the participants got a score on the Likert scale of 7, which is above the average of life satisfaction.

According to the chapters, no difference was observed when the "life satisfaction scale" and "leisure time scale" were examined.

When the averages of " Meaning of Empty Time Meaning " according to the classes are examined, it is seen that there is a meaningful difference between the groups. This difference appears to be between the 2nd and 3rd classes when examined on a class-by-class basis.

When the life satisfaction scale according to the classes was examined, no difference was observed.

\section{References}

Demirel, H. (2014). An investigation of the relationship between job and life satisfaction among teachers. Procedia Social and Behavioral Sciences, 116, 4925-4931. https://doi.org/10.1016/j.sbspro.2014.01.1051 
Diener, E., Emmons, R., Larsen, R., \& Griffin, S. (1985). The Satisfaction With Life Scale. Journal of Personality Assessment, 49, 71-75. https://doi.org/10.1207/s15327752jpa4901_13

Dikmen, A. A. (1995). İş Doyumu ve Yaşam Doyumu İlişkisi (Unpublished master’s thesis). A.Ü. Sosyal Bilimler Enstitüsü Kamu Yönetimi ve Siyaset Bilimi (Yönetim Bilimi) A.B.D.

Esteve, R., Martin, J. S., \& Lopez, A. E. (1999). Grasping The Meaning Of Leisure: Developing A Self Report Measurement Tool. Leisure Studies, 18(2), 79-91. https://doi.org/10.1080/026143699374961

Gökçe, H. (2008). Serbest Zaman Doyumunun Yaşam Doyumu ve Sosyo-Demografik Değişkenlerle İliş̧isinin Incelenmesi (Unpublished master's thesis). Pamukkale University, Denizli

Gürbüz, B., Özdemir, A. S., \& Karaküçük, S. (2009). Leisure Meanings Inventory: Evaluation of Psycho-metric Characteristics on Turkish University Students. 4th International Mediterranean Sport Science Congress, 66, 9-11. Kasım, Antalya, Turkiye.

Karaküçük, S. (1999). Rekreasyon Boş Zamanları Değerlendirme. Gazi Kitabevi, ANKARA.

Karataş, S. (1988). Yaşlılarda Yaşam Doyumunu Etkileyen Etmenler (Unpublished master's thesis). Hacettepe Üniversitesi Sosyal Bilimler Enstitüsü, Yüksek Lisans Tezi, Ankara, Cited : ŞENER A. (2009). Yaşl1lık, Yaşam Doyumu ve Boş Zaman Faaliyetleri, Hacettepe Üniversitesi Sosyolojik Araştırmalar E-Dergisi. Retrieved from http://www.sdergi.hacettepe.edu.tr/makaleler/yasamdoyumu.pdf

Karataş, S. (1989). Huzurevinde Kalan Yaşlıların Yaşam Doyum Düzeyleri ile Ölüm Kaygıları Arasındaki İlişki: XXV. Ulusal Psikiyatri ve Nörolojik Bilimler Kongresi, Mersin, 675-677. Cited: Şener A. (2009). Yaşl1lık, Yaşam Doyumu ve Boş Zaman Faaliyetleri, Hacettepe Üniversitesi Sosyolojik Araştırmalar E-Dergisi

Köker, S. (1991). Normal ve Sorunlu Ergenlerin Yaşam Doyumu Düzeyinin Karşılaştırılması. (Unpublished master's thesis). Ankara University, Ankara

Mieczkowski, Z. (1990). World Trends in Tourism and Recreation, Peter Lang Publishing, New York,

Özdevecioğlu, M. (2003). İş Tatmini ve Yaşam Tatmini Arasındaki İlişkinin Belirlenmesine Yönelik Bir Araştırma. 11.Ulusal Yönetim ve Organizasyon Kongresi, 22- 24 May, Afyon, 697.

Rodriguez, A., Latkova, P., \& Sun, Y. (2007). The The relationship between leisure and life satisfaction: application of activity and need theory, Springer Science+Business Media B.V. https://doi.org/10.1007/s11205-007-9101-y

Schmitter, C. A. (2003). "Life Satisfaction in Centenarians Residing in Long-Term Care, http://www.mmhc.com/articles/NHM9912/cutillo.html, Cited: Capri, B., Özkendir, O. M., Özkurt, B. \& Karakuş, F. (2012). General self-efficacy beliefs, life satisfaction and burnout of university students. Procedia Social and Behavioral Sciences, 47, 968-973. https://doi.org/10.1016/j.sbspro.2012.06.765

Süzer (2000). Üniversite ğrencilerinin Boş Zamanlarını Değerlendirme Alışkanlıkları. Pamukkale Üniversitesi Eğitim Fakültesi Dergisi, 8(8), 123-133.

Tillman, A. (1974). The Program Book for Recreation Professionals. National Press Books, Palo Alto, CA.

Torkildsen, G. (2005). Leisure and Recreation Management., 5 th ed. Routledge, Taylor and Francis Group, London, England. https://doi.org/10.4324/9780203401651

\section{Copyrights}

Copyright for this article is retained by the author(s), with first publication rights granted to the journal.

This is an open-access article distributed under the terms and conditions of the Creative Commons Attribution license which permits unrestricted use, distribution, and reproduction in any medium, provided the original work is properly cited. 